\title{
PENINGKATAN EFESIENSI ENERGI GEDUNG L2 FAKULTAS TEKNIK UNIVERSITAS NEGERI JAKARTA MELALUI AUDIT ENERGI KELISTRIKAN DALAM RANGKA DETEKSI DINI TERHADAP BAHAYA KEBAKARAN
}

${ }^{1}$ Massus Subekti, ${ }^{2}$ Irzan Zakir, ${ }^{3}$ Imam Arif Rahardjo

${ }^{1,2,3}$ Pendidikan Teknik Elektro, Fakultas Teknik, Universitas Negeri Jakarta.

${ }^{1}$ Email : masus@unj.ac.id

\begin{abstract}
This study aims to identify the magnitude of energy consumption currently used and identify all possible energy savings including detecting all possible fire hazards based on audit data obtained using Power Quality Analizer (PQA) and Thermal Imager.

The methods included include: collection and introduction of historical data, calculating IKE, measuring real power $(k W)$ / apparent power ( $k V A)$, power factor, maximum / minimum frequency, voltage / current between phases, voltage / load unbalance, voltage harmonic / flow, checking Energy Consumption Intensity (IKE), recognizing the possibility of Energy Saving Opportunities (PHE), analyzing PHE, Making PHE recommendations and implementing PHE in the field to obtain the value of Energy Consumption Instances according to standards. Based on the measurement results show the carrying frequency, voltage fluctuations, voltage harmonics, and voltage imbalances are still in accordance with the standard. So that it can be concluded that the Faculty of Engineering, Jakarta State University, is still safe from the danger of building fires.
\end{abstract}

Keywords: Efficiency, Building, Energy Audit, Fire

\begin{abstract}
Abstrak
Penelitian ini bertujuan dilakukan guna mengidentifikasi besarnya konsumsi energi yang saat ini digunakan dan mengidentifikasi segala kemungkinan penghematan energy termasuk mendeteksi segala kemungkinan bahaya kebakaran berdasarkan data audit yang diperoleh dengan menggunakan Power Quality Analizer (PQA) dan Thermal Imager.

Metode yang dilakukan meliputi: pengumpulan dan penyusuan data historis, menghitung IKE, melakukan pengukuran daya nyata $(\mathrm{kW}) /$ daya semu $(\mathrm{kVA})$, faktor daya, frekwensi maksimum/minimum, tegangan/ antar phasa, unbalance tegangan/beban, harmonik tegangan/, pemeriksaan Intensitas Konsumsi Energi (IKE), mengenali kemungkinan Peluang Hemat Energi (PHE), menganalisa PHE, Membuat rekomendasi PHE serta mengimplementasikan PHE dilapangan guna mendapatkan nilai Instensitas Konsumsi Energi sesuai standar. Berdasarkan hasil pengukuran menunjukkan bawa frekuensi, fluktuasi tegangan ,harmonisa tegangan, dan ketidakseimbangan tegangan masih dalam sesuai dengan standar. Sehingga dapat disimpulkan bahwa Fakultas Teknik Universitas Negeri Jakarta dari sisi kelistrikan masih aman dari bahaya kebakaran gedung.

Kata Kunci: Efesiensi, Gedung, Audit Energi, Kebakaran
\end{abstract}

\section{PENDAHULUAN}

Sebagai salah satu upaya untuk menurunkan pemakaian energi nasional pemerintah telah mengeluarkan kebijakan konservasi energi. Sebagai kebijakan energi nasional, program konservasi energi telah cukup kuat memiliki landasan hukum ini terutama dengan telah adanya Undang Undang No.30 tentang Energi, yang kemudian di tindaklanjuti dengan Peraturan Pemerintah No. 70 Tahun 2009 tentang Konservasi Energi yang mewajibkan pengguna energi diatas 6000 TOE untuk melaksanakan Konservasi Energi yaitu menunjuk Manajer Energi, menyusun program Konservasi Energi, melaksanakan Audit Energi secara berkala, melaksanakan rekomendasi hasil audit energi, dan melaporkan hasil pelaksanaan Manajemen Energi setiap tahun.

Selain itu tahun 2011, telah dikeluarkan Instruksi Presiden Nomor 13 Tahun 2011 sebagai pengganti Instruksi Presiden Nomor 2 Tahun 2008 mengenai Penghematan Energi dan Air. Secara substantif, Inpres tersebut meminta seluruh instansi pemerintah melakukan penghematan energi dan air di tempatnya serta membentuk gugus tugas untuk mengawasi pelaksanaan penghematan energi dan air. Namun pada kenyataannya proses audit energi masih jarang diterapkan di Indonesia terutama bagi gedung komersial seperti gedung perkantoran, sekolah, rumah sakit termasuk universitas.

Sebagai salah satu lembaga pemerintah yang sangat tergantung terhadap kebutuhan energi 
listrik Universitas Negeri Jakarta dituntut untuk dapat melakukan efesiensi energi dalam bentuk audit energi terhadap semua gedung salah satunya gedung L Fakultas Teknik yang merupakan salah satu gedung lama yang telah mengalami banyak perubahan beban listrik akibat dari penambahan $\mathrm{AC}$ dan perubahan ruang. Audit tersebut dilakukan guna mengidentifikasi besarnya konsumsi energi yang saat ini digunakan dan mengidentifikasi segala kemungkinan penghematan energi termasuk mendeteksi segala kemungkinan bahaya kebakaran yang banyak terjadi di beberapa kampus diantaranya yang terbaru Universitas Parahyangan Bandung pada 21 Mar 2017 dan Institut Pertanian Bogor (IPB) Dramaga, Kabupaten Bogor pada 29 Maret 2017 berdasarkan data audit yang diperoleh dengan menggunakan Power Quality Analizer (PQA) dan Thermal Imager.

\section{METODE}

Penelitian dilakukan di gedung L Fakultas Teknik Univeritas Negeri selama 10 bulan di tahun 2017

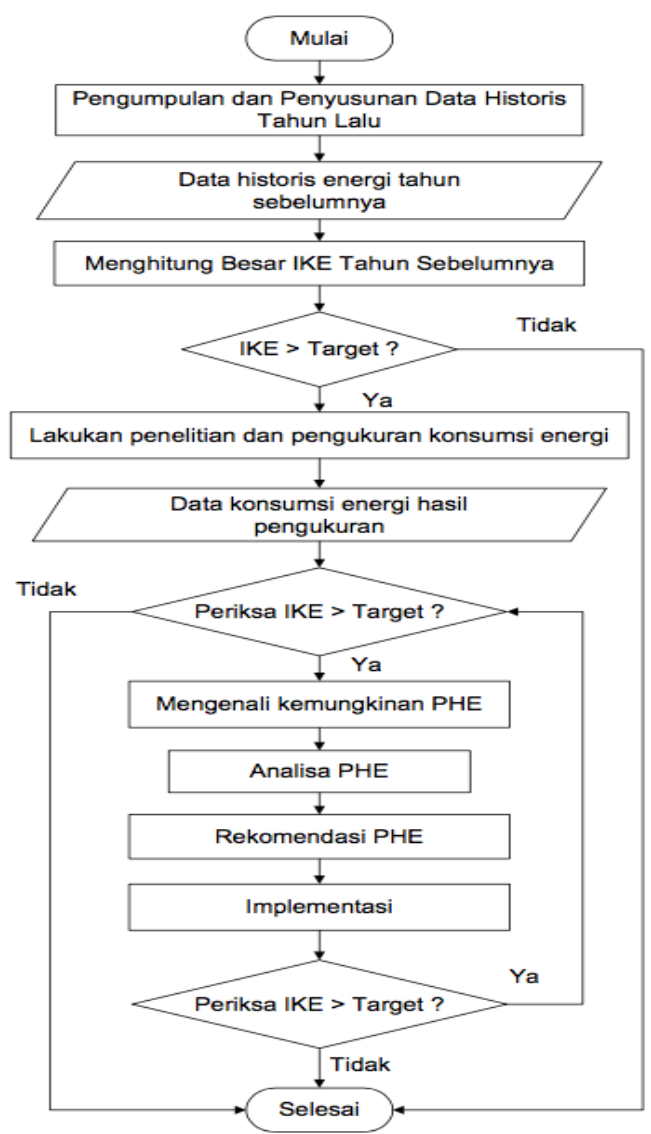

Gambar 1. Alur Penelitian
HASIL DAN PEMBAHASAN

Beban Terpasang

a. Beban Panel Penerangan Lantai 1

Tabel 1 Pemakaian Komponen dan Beban Lantai 1 Panel Penerangan

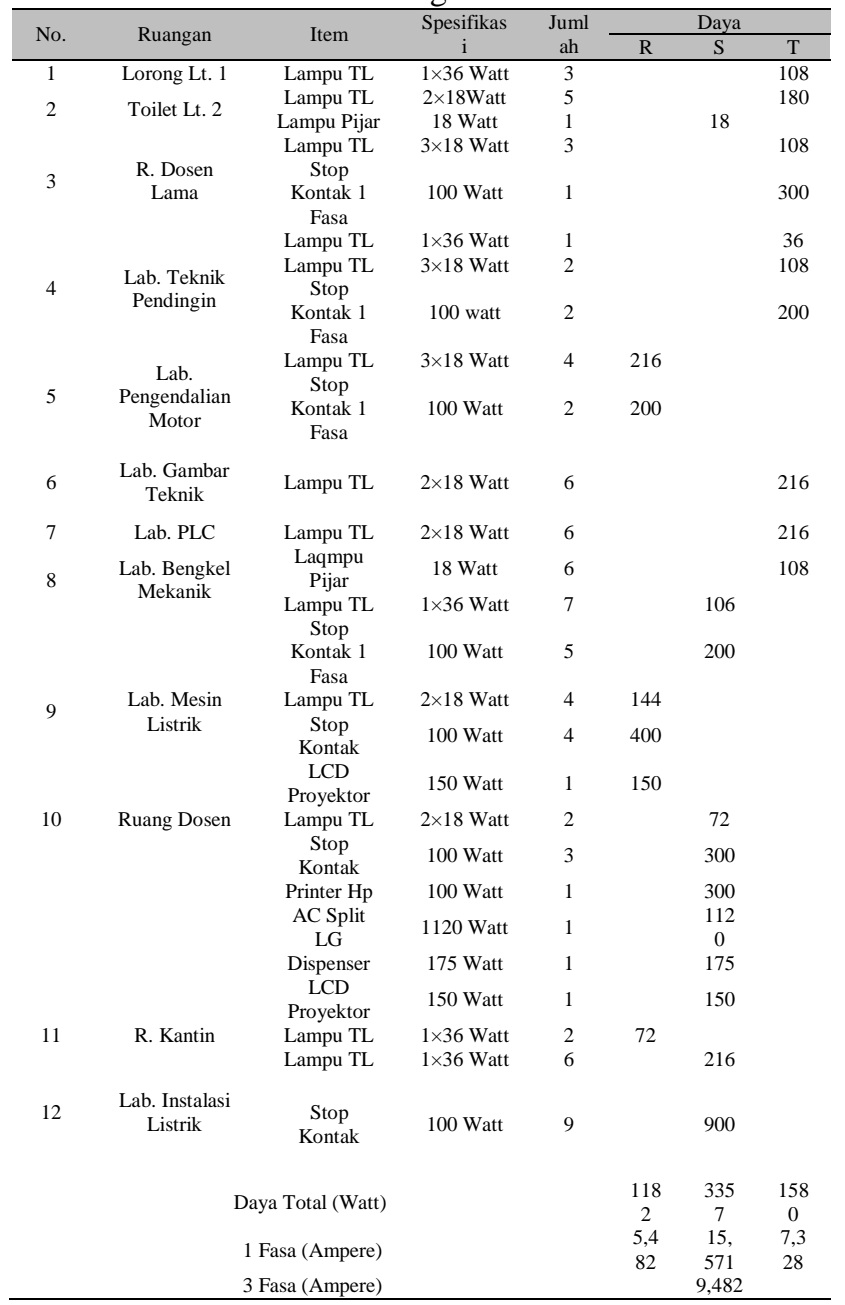

Berdasarkan data ini ada perbedaan antara beban pengaman yang digunakan pada panel penerangan lantai 1 , kapasitas pengaman $\mathrm{MCB}$ 3 Fasa 40A dengan data analisis beban panel Penerangan lantai 1 kapasitas MCB 3 Fasa 9,487A. Dan data ini sudah terlihat perbedaan penggunaan beban antara fasa $R, S, T$ perbedaan selisi beban fasa $\mathrm{R}-\mathrm{S}$ adalah 2175 watt, selisi beban fasa $\mathrm{S}-\mathrm{T}$ adalah 1777 watt, dan selisi beban fasa $\mathrm{R}$ - T adalah 398 watt. Hal ini tidak sesuai dengan kriteria kehandalan instalasi listrik yang mensyaratkan penggunaan pembatas sesuai dengan pemakaian beban.

\section{b. Beban Panel AC Lantai 1}

Berdasarkan data ada perbedaan antara beban pengaman yang digunakan pada panel AC lantai 1, kapasitas pengaman MCB 3 Fasa 40A dengan data analisis beban panel AC lantai 1 kapasitas MCB 3 Fasa 30,158A. Dan data ini sudah terlihat 
perbedaan penggunaan beban antara fasa $R, S, T$ perbedaan selisi beban fasa $\mathrm{R}-\mathrm{S}$ adalah 11.490 watt, selisi beban fasa $\mathrm{S}$ - T adalah 402 watt, dan selisi beban fasa $\mathrm{R}-\mathrm{T}$ adalah 11.088 watt. Hal ini tidak sesuai dengan penggunaan pembatas sesuai dengan pemakaian beban.

Tabel 2 Pemakaian Komponen dan Beban Lantai 1 Panel

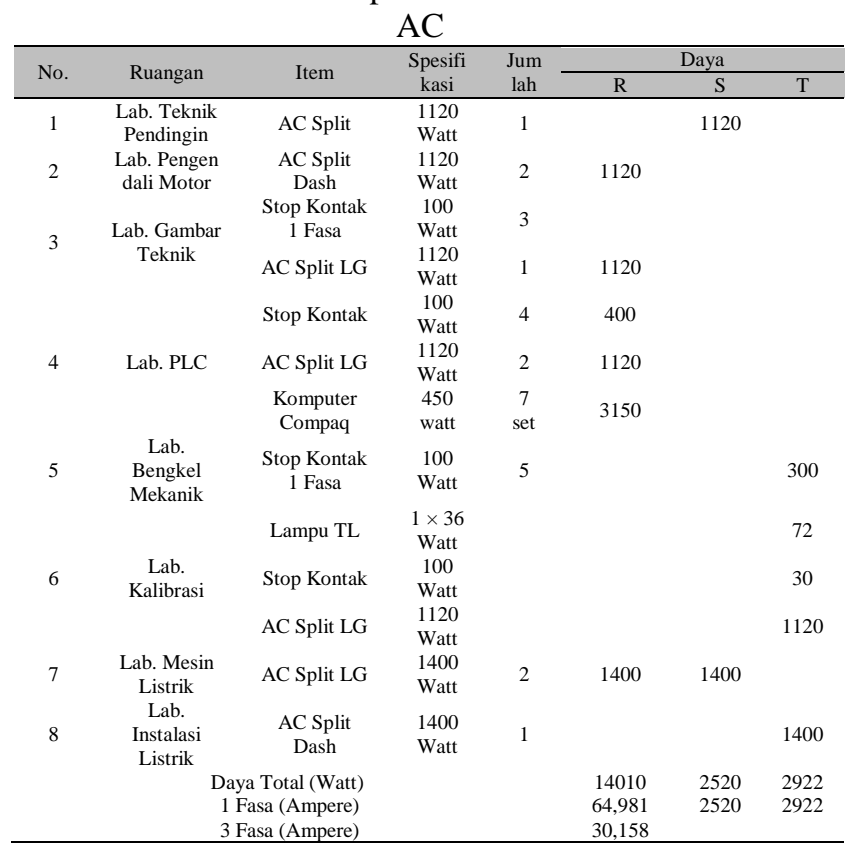

c. Beban Panel AC Lantai 1

Tabel 3 Pemakaian Komponen dan Beban Lantai 1 Panel

\begin{tabular}{|c|c|c|c|c|c|c|c|}
\hline \multicolumn{8}{|c|}{ Daya } \\
\hline \multirow{2}{*}{ No. } & \multirow{2}{*}{ Ruangan } & \multirow{2}{*}{ Item } & \multirow{2}{*}{$\begin{array}{c}\text { Spesifi } \\
\text { kasi }\end{array}$} & \multirow{2}{*}{$\begin{array}{l}\text { Jum } \\
\text { lah }\end{array}$} & \multicolumn{3}{|c|}{ Daya } \\
\hline & & & & & $\mathrm{R}$ & $\mathrm{S}$ & $\mathrm{T}$ \\
\hline 1 & $\begin{array}{c}\text { Lab. } \\
\text { Pengendali } \\
\text { Motor }\end{array}$ & $\begin{array}{c}\text { Stop Kontak } \\
3 \text { Fasa }\end{array}$ & $\begin{array}{l}1000 \\
\text { Watt }\end{array}$ & 2 & 2000 & 2000 & 2000 \\
\hline \multirow[t]{2}{*}{2} & $\begin{array}{c}\text { Ruang } \\
\text { Gudang }\end{array}$ & Lampu TL & $\begin{array}{l}1 \times 36 \\
\text { Watt }\end{array}$ & 2 & & & 72 \\
\hline & Lab. & Stop Kontak & $\begin{array}{l}100 \\
\text { Watt }\end{array}$ & 3 & & 200 & \\
\hline \multirow[t]{2}{*}{3} & Bengkel & Lampu TL & $\begin{array}{l}1 \times 36 \\
\text { Watt }\end{array}$ & 7 & & & 144 \\
\hline & & AC Split LG & $\begin{array}{l}1120 \\
\text { Watt }\end{array}$ & 1 & & & 1120 \\
\hline \multirow[t]{4}{*}{4} & $\begin{array}{l}\text { Lab. Mesin } \\
\text { Listrik }\end{array}$ & $\begin{array}{l}\text { Stop Kontak } \\
3 \text { Fasa }\end{array}$ & $\begin{array}{l}1000 \\
\text { Watt }\end{array}$ & 2 & 2000 & 2000 & 2000 \\
\hline & \multirow{2}{*}{\multicolumn{3}{|c|}{$\begin{array}{c}\text { Daya Total (Watt) } \\
1 \text { Fasa (Ampere) }\end{array}$}} & & 6150 & 6200 & 7336 \\
\hline & & & & & 28,52 & $\begin{array}{r}28,75 \\
30,52\end{array}$ & 34,02 \\
\hline & \multicolumn{3}{|c|}{3 Fasa (Ampere) } & & & 30,521 & \\
\hline
\end{tabular}

Berdasarkan data ini ada perbedaan antara beban pengaman yang digunakan pada panel Daya lantai 1 , kapasitas pengaman MCB 3 Fasa 50A dengan data analisis beban panel daya lantai 1 kapasitas MCB 3 Fasa 30,521A. Dan data ini sudah terlihat perbedaan. Penggunaan beban antara fasa $R, S$, T perbedaan selisi beban fasa $R$ - $\mathrm{S}$ adalah 50 watt, selisih beban fasa $\mathrm{S}-\mathrm{T}$ adalah 1.136 watt, dan selisi beban fasa $\mathrm{R}-\mathrm{T}$ adalah 1.186 watt. Hal ini tidak sesuai dengan kriteria kehandalan instalasi listrik yang mensyaratkan penggunaan pembatas sesuai dengan pemakaian beban. d. Beban Panel Penerangan Lantai 2

Tabel 4 Pemakaian Komponen dan Beban Lantai 2 Panel

\begin{tabular}{|c|c|c|c|c|c|c|c|}
\hline \multicolumn{8}{|c|}{ Penerangan } \\
\hline \multirow{2}{*}{ No. } & \multirow{2}{*}{ Ruangan } & \multirow{2}{*}{ Item } & \multirow{2}{*}{$\begin{array}{c}\text { Spesifi } \\
\text { kasi }\end{array}$} & \multirow{2}{*}{$\begin{array}{l}\text { Jum } \\
\text { lah }\end{array}$} & \multicolumn{3}{|c|}{ Daya } \\
\hline & & & & & $\mathrm{R}$ & $\mathrm{S}$ & $\mathrm{T}$ \\
\hline 1 & Lorong Lt. 2 & Lampu TL & $\begin{array}{l}1 \times 36 \\
\text { Watt }\end{array}$ & 5 & 180 & & \\
\hline \multirow[t]{2}{*}{2} & \multirow[t]{2}{*}{ Toilet Lt. 2} & Lampu TL & $\begin{array}{l}1 \times 36 \\
\text { Watt }\end{array}$ & 2 & 72 & & \\
\hline & & Lampu TL & $\begin{array}{l}3 \times 18 \\
\text { Watt }\end{array}$ & 4 & 216 & & \\
\hline \multirow[t]{4}{*}{3} & \multirow[t]{4}{*}{ Dosen / 202} & $\begin{array}{c}\text { Stop Kontak } \\
1 \text { Fasa }\end{array}$ & $\begin{array}{c}100 \\
\text { Watt }\end{array}$ & 2 & 100 & & \\
\hline & & Dispenser & $\begin{array}{c}175 \\
\text { Watt }\end{array}$ & 1 & 175 & & \\
\hline & & Lampu TL & $\begin{array}{l}1 \times 36 \\
\text { Watt }\end{array}$ & 3 & & & 108 \\
\hline & & Lampu TL & $\begin{array}{l}1 \times 36 \\
\text { Watt }\end{array}$ & 9 & & 486 & \\
\hline \multirow[t]{6}{*}{4} & \multirow{6}{*}{$\begin{array}{l}\text { Lab. Fisika } \\
\text { Dasar / } 208\end{array}$} & Lampu Pijar & $\begin{array}{l}1120 \\
\text { Watt }\end{array}$ & 1 & & 18 & \\
\hline & & $\begin{array}{c}\text { Stop } \\
\text { Konatak } 1 \\
\text { Fasa }\end{array}$ & $\begin{array}{c}100 \\
\text { Watt }\end{array}$ & 2 & & & 200 \\
\hline & & $\begin{array}{l}\text { Komputer } \\
\text { Compaq }\end{array}$ & $\begin{array}{c}450 \\
\text { Watt }\end{array}$ & 2set & & & 900 \\
\hline & & Lampu TL & $\begin{array}{l}1000 \\
\text { Watt }\end{array}$ & 2 & & 108 & \\
\hline & & $\begin{array}{l}\text { Stop Kontak } \\
1 \text { fasa }\end{array}$ & $\begin{array}{c}100 \\
\text { Watt }\end{array}$ & 2 & & & 200 \\
\hline & & $\begin{array}{c}\text { Stop Kontak } \\
1 \text { Fasa }\end{array}$ & $\begin{array}{c}100 \\
\text { Watt }\end{array}$ & 1 & & & 100 \\
\hline \multirow{4}{*}{5} & \multirow{4}{*}{ Dosen / 207} & Televisi & $\begin{array}{c}200 \\
\text { Watt }\end{array}$ & 1 & & & 200 \\
\hline & & Printer Hp & $\begin{array}{c}100 \\
\text { Watt }\end{array}$ & 1 & & & 100 \\
\hline & & Kipas Angin & $\begin{array}{c}150 \\
\text { Watt }\end{array}$ & 1 & & & 150 \\
\hline & & Lampu TL & $\begin{array}{l}1 \times 36 \\
\text { Watt }\end{array}$ & 1 & & 36 & \\
\hline \multirow[t]{3}{*}{6} & \multirow[t]{3}{*}{ Dosen / 206} & Lampu TL & $\begin{array}{l}2 \times 18 \\
\text { Watt }\end{array}$ & 1 & & 36 & \\
\hline & & $\begin{array}{l}\text { Stop Kontak } \\
1 \text { Fasa }\end{array}$ & $\begin{array}{c}100 \\
\text { Watt }\end{array}$ & 3 & & 300 & \\
\hline & & Lampu TL & $\begin{array}{l}1 \times 36 \\
\text { Watt }\end{array}$ & 3 & & 108 & \\
\hline \multirow[t]{4}{*}{7} & \multirow[t]{3}{*}{ Dosen / 205} & Lampu TL & $\begin{array}{l}2 \times 18 \\
\text { Watt }\end{array}$ & 1 & & 36 & \\
\hline & & $\begin{array}{l}\text { Stop Kontak } \\
1 \text { Fasa }\end{array}$ & $\begin{array}{c}100 \\
\text { Watt }\end{array}$ & 3 & & 300 & \\
\hline & & Lampu TL & $\begin{array}{l}1 \times 36 \\
\text { Watt }\end{array}$ & 1 & & 36 & \\
\hline & & $\begin{array}{c}\text { Stop Kontak } \\
1 \text { Fasa }\end{array}$ & $\begin{array}{l}100 \\
\text { watt }\end{array}$ & 1 & & 100 & \\
\hline 8 & Administrasi & $\begin{array}{c}\text { Komputer } \\
\text { Acer }\end{array}$ & $\begin{array}{l}450 \\
\text { Watt }\end{array}$ & $\begin{array}{c}1 \\
\text { Set }\end{array}$ & & 450 & \\
\hline & & Printer Hp & $\begin{array}{c}100 \\
\text { Watt }\end{array}$ & 1 & & 100 & \\
\hline 9 & Anjungan & Lampu TL & $\begin{array}{l}2 \times 36 \\
\text { Watt }\end{array}$ & 2 & 144 & & \\
\hline & & $\begin{array}{c}\text { Komputer } \\
\text { Acer }\end{array}$ & $\begin{array}{l}450 \\
\text { Watt }\end{array}$ & $\begin{array}{c}2 \\
\text { Set }\end{array}$ & 900 & & \\
\hline & & Lampu TL & $\begin{array}{l}2 \times 36 \\
\text { Watt }\end{array}$ & 2 & 144 & & \\
\hline & & $\begin{array}{l}\text { Komputer } \\
\text { Acer }\end{array}$ & $\begin{array}{l}450 \\
\text { Watt }\end{array}$ & 1 & 450 & & \\
\hline & & Printer Hp & $\begin{array}{c}100 \\
\text { Watt }\end{array}$ & 1 & 100 & & \\
\hline & & $\begin{array}{c}\text { Stop Kontak } \\
1 \text { Fasa }\end{array}$ & $\begin{array}{c}100 \\
\text { Watt }\end{array}$ & 1 & 100 & & \\
\hline & & Lampu TL & $\begin{array}{l}2 \times 36 \\
\text { Watt }\end{array}$ & 2 & & 144 & \\
\hline & & $\begin{array}{l}\text { Stop Kontak } \\
1 \text { Fasa }\end{array}$ & $\begin{array}{c}100 \\
\text { Watt }\end{array}$ & 3 & 300 & & \\
\hline & & Printer Hp & $\begin{array}{c}100 \\
\text { Watt }\end{array}$ & 1 & 100 & & \\
\hline & & $\begin{array}{c}\text { Televisi } \\
\text { Panasonic }\end{array}$ & $\begin{array}{c}200 \\
\text { Watt }\end{array}$ & 1 & 200 & & \\
\hline & & Total (Watt) & & & 3181 & 2258 & 1958 \\
\hline & & asa (Ampere) & & & 14,754 & 10,473 & 9,082 \\
\hline & & asa (Ampere) & & & & 11,468 & \\
\hline
\end{tabular}

Berdasarkan data ini ada perbedaan antara beban pengaman yang digunakan pada panel penerangan lantai 2 , kapasitas pengaman MCB 3 Fasa 40A dengan data analisis beban panel Penerangan lantai 2 kapasitas MCB 3 Fasa 11,468A. Dan data ini sudah terlihat perbedaan penggunaan beban antara fasa $R, S, T$ perbedaan selisi beban fasa $\mathrm{R}-\mathrm{S}$ adalah 923 watt, selisih 
beban fasa $\mathrm{S}-\mathrm{T}$ adalah 300 watt, dan selisi beban fasa $\mathrm{R}-\mathrm{T}$ adalah 1.223 watt. Hal ini tidak sesuai dengan kriteria kehandalan instalasi listrik yang mensyaratkan penggunaan pembatas sesuai dengan pemakaian beban.

\section{e. Beban Panel AC Lantai 2}

Tabel 5 Pemakaian Komponen dan Beban Lantai 2 Panel AC

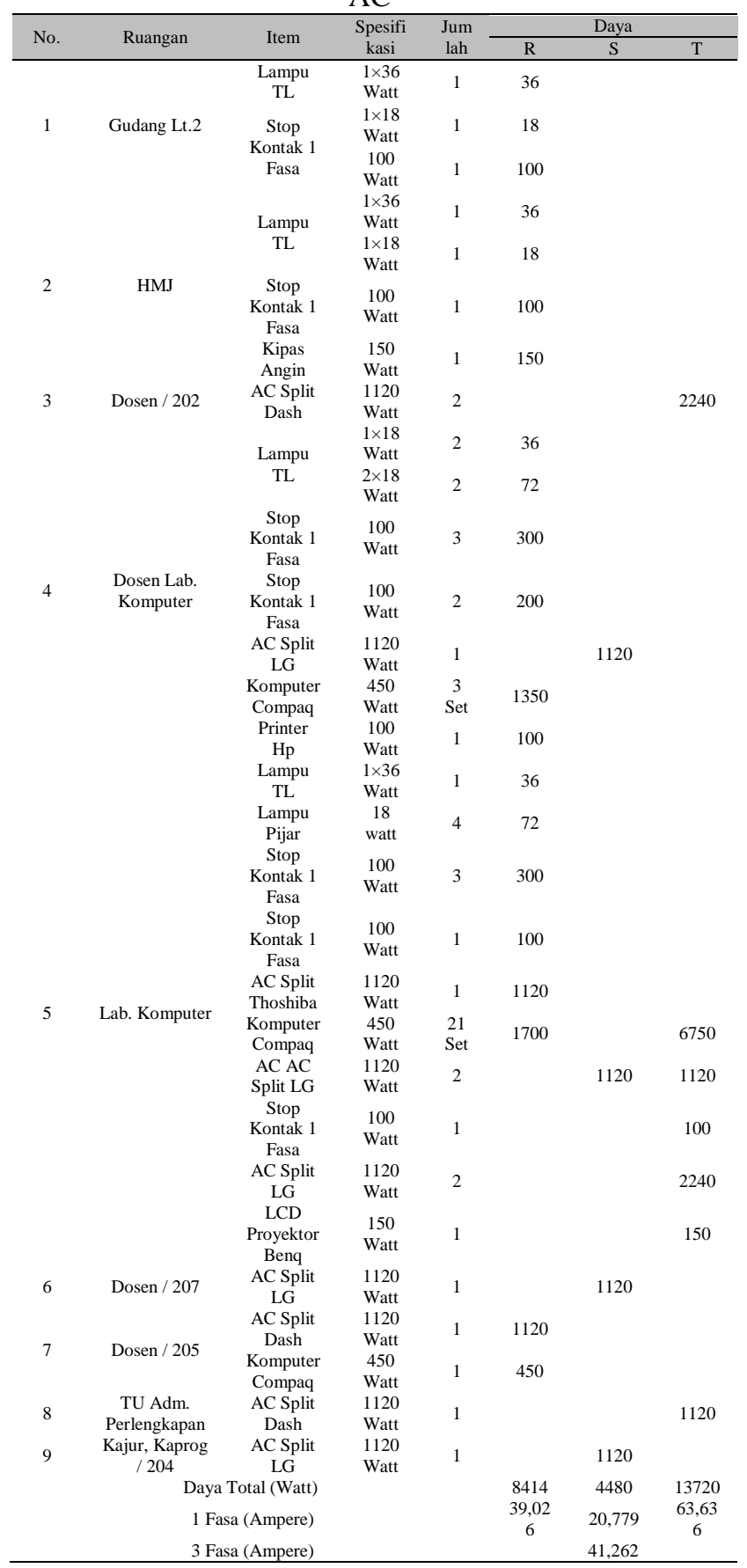

Berdasarkan data ini ada perbedaan antara beban pengaman yang digunakan pada panel AC lantai 2 , kapasitas pengaman MCB 3 Fasa 40A dengan data analisis beban panel AC lantai 2 kapasitas MCB 3 Fasa 41,262A. Dan data ini sudah terlihat perbedaan penggunaan beban antara fasa $\mathrm{R}, \mathrm{S}, \mathrm{T}$ perbedaan selisi beban fasa $\mathrm{R}$ - $\mathrm{S}$ adalah 3.934 watt, selisi beban fasa $\mathrm{S}-\mathrm{T}$ adalah 9.240 watt, dan selisi beban fasa $\mathrm{R}-\mathrm{T}$ adalah 5.306 watt. Ada perbedaan yang terlihat pada fasa $\mathrm{T}$ dengan penggunaan ruang lab. komputer lantai 2 menggunakan hanya 1 fasa saja. Hal ini tidak sesuai dengan kriteria kehandalan instalasi listrik yang mensyaratkan penggunaan pembatas sesuai dengan pemakaian beban.

\section{f. Beban Panel Penerangan Lantai 3}

Tabel 6. Pemakaian Komponen dan Beban Lantai 3 Panel

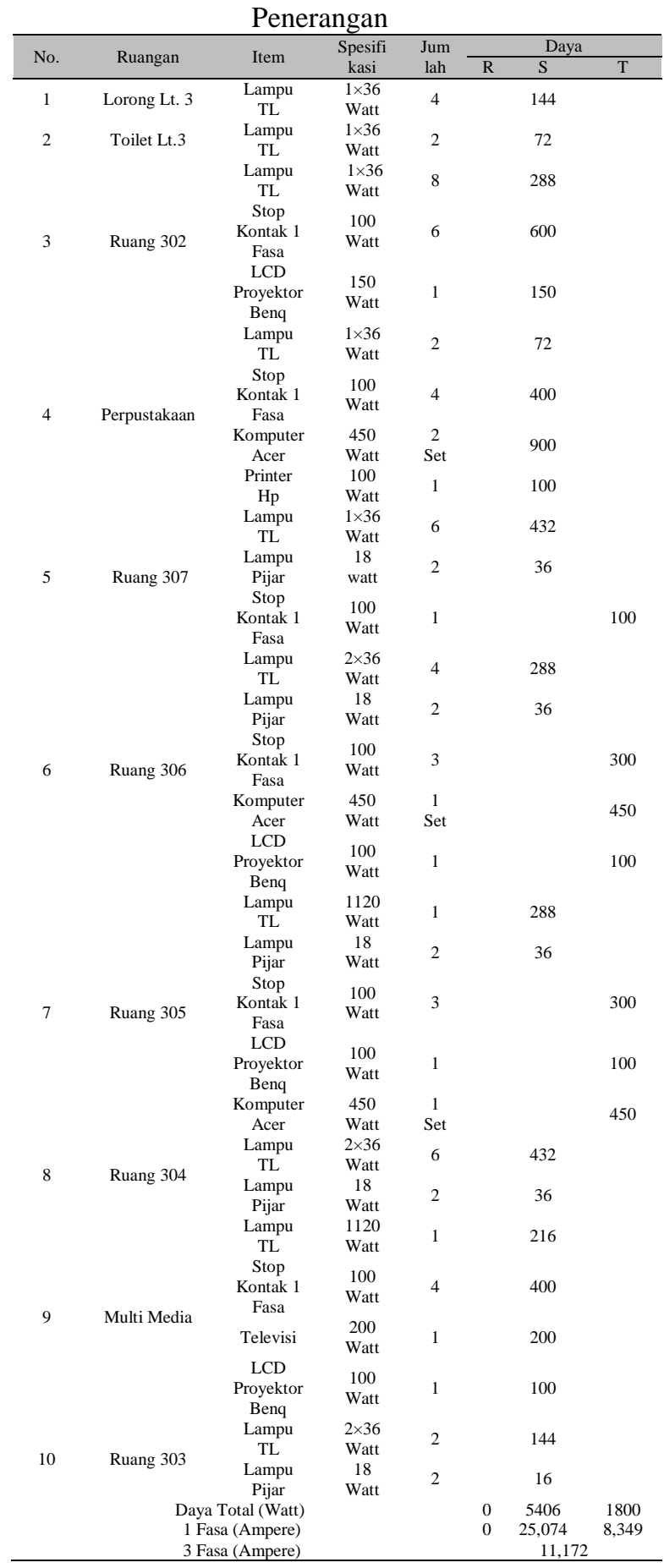


Berdasarkan data tabel 6 ada perbedaan antara beban pengaman yang digunakan pada panel penerangan lantai 3 , kapasitas pengaman MCB 3 Fasa 40A dengan data analisis beban panel Penerangan lantai 3 kapasitas MCB 3 Fasa 11,172. Dan data ini sudah terlihat perbedaan penggunaan beban antara fasa $\mathrm{R}, \mathrm{S}, \mathrm{T}$ perbedaan selisi beban fasa $\mathrm{R}-\mathrm{S}$ adalah 5.406 watt, selisi beban fasa $\mathrm{S}-\mathrm{T}$ adalah 3.606 watt, dan selisi beban fasa $\mathrm{R}-\mathrm{T}$ adalah 1.800 watt. Hal ini tidak sesuai dengan kriteria kehandalan instalasi listrik yang mensyaratkan penggunaan pembatas sesuai dengan pemakaian beban.

g. Beban Panel AC Lantai 3

Tabel 7. Pemakaian Komponen dan Beban Lantai 3 Panel AC

\begin{tabular}{|c|c|c|c|c|c|c|c|}
\hline \multirow{2}{*}{ No. } & \multirow{2}{*}{ Ruangan } & \multirow{2}{*}{ Item } & \multirow{2}{*}{$\begin{array}{l}\text { Spesifi } \\
\text { kasi }\end{array}$} & \multirow{2}{*}{$\begin{array}{l}\text { Jum } \\
\text { lah }\end{array}$} & \multicolumn{3}{|c|}{ Daya } \\
\hline & & & & & $\mathrm{R}$ & $\mathrm{S}$ & $\mathrm{T}$ \\
\hline \multirow{3}{*}{1} & \multirow{3}{*}{ Ruang 302} & $\begin{array}{l}\text { AC Split } \\
\text { Autech }\end{array}$ & $\begin{array}{l}1120 \\
\text { Watt }\end{array}$ & 1 & 1120 & & \\
\hline & & Ac Split & 1120 & 1 & & & 1120 \\
\hline & & LG & Watt & 1 & & & 1120 \\
\hline \multirow[t]{4}{*}{2} & \multirow[t]{2}{*}{ Perpustakaan } & AC Split & 1120 & 1 & & 112 & \\
\hline & & $\begin{array}{l}\text { National } \\
\text { Stop }\end{array}$ & Watt & & & 0 & \\
\hline & \multirow{5}{*}{ Ruang 307} & $\begin{array}{c}\text { Kontak } 1 \\
\text { Fasa }\end{array}$ & $\begin{array}{l}100 \\
\text { Watt }\end{array}$ & 3 & & 300 & \\
\hline & & AC Split & 1120 & 2 & & 112 & \\
\hline \multirow[t]{4}{*}{3} & & & & & & & \\
\hline & & $\begin{array}{l}\text { LCD } \\
\text { Proyektor } \\
\text { Benq }\end{array}$ & $\begin{array}{l}100 \\
\text { Watt }\end{array}$ & 1 & & 100 & \\
\hline & & Komputer & 450 & 1 & & 450 & \\
\hline & \multirow{2}{*}{ Ruang 306} & $\begin{array}{c}\text { Acer } \\
\text { AC Split }\end{array}$ & $\begin{array}{l}\text { Watt } \\
1120\end{array}$ & Set & & 112 & \\
\hline 4 & & Panasonic & Watt & 1 & & 0 & \\
\hline \multirow[t]{3}{*}{5} & \multirow[t]{3}{*}{ Ruang 305} & $\begin{array}{l}\text { AC Split } \\
\text { Panasonic }\end{array}$ & $\begin{array}{l}1120 \\
\text { Watt }\end{array}$ & 1 & 1120 & & \\
\hline & & AC Split & 1120 & 2 & 120 & & \\
\hline & & $\begin{array}{l}\text { Panasonic } \\
\text { Stop }\end{array}$ & Watt & & & & \\
\hline \multirow[t]{5}{*}{6} & \multirow[t]{4}{*}{ Ruang 304} & $\begin{array}{c}\text { Kontak } 1 \\
\text { Fasa }\end{array}$ & $\begin{array}{c}100 \\
\text { Watt }\end{array}$ & 3 & 1120 & & \\
\hline & & $\begin{array}{c}\text { Komputer } \\
\text { Acer }\end{array}$ & $\begin{array}{l}450 \\
\text { Watt }\end{array}$ & $\begin{array}{c}1 \\
\text { Set }\end{array}$ & 300 & & \\
\hline & & Kipas & 150 & 2 & 450 & & \\
\hline & & $\begin{array}{l}\text { Angin } \\
A C \text { Snlit }\end{array}$ & Watt & & & & \\
\hline & \multirow{2}{*}{ Multi Media } & $\begin{array}{l}\text { AC Split } \\
\text { Panasonic }\end{array}$ & $\begin{array}{l}1120 \\
\text { Watt }\end{array}$ & 2 & & & 2240 \\
\hline \multirow{2}{*}{7} & & $\begin{array}{c}\text { Komputer } \\
\text { Compaq }\end{array}$ & $\begin{array}{l}450 \\
\text { Watt }\end{array}$ & $\begin{array}{l}15 \\
\text { Set }\end{array}$ & 6750 & & \\
\hline & & $\begin{array}{c}\text { Stop } \\
\text { Kontak } 1 \\
\text { Fasa }\end{array}$ & $\begin{array}{l}100 \\
\text { Watt }\end{array}$ & 3 & & & 300 \\
\hline \multirow[t]{5}{*}{8} & Ruang 303 & $\begin{array}{c}\text { AC Split } \\
\text { Panasonic }\end{array}$ & $\begin{array}{l}1120 \\
\text { Watt }\end{array}$ & 1 & 1120 & & \\
\hline & & $\begin{array}{c}\text { LCD } \\
\text { Proyektor } \\
\text { Benq }\end{array}$ & $\begin{array}{l}100 \\
\text { Watt }\end{array}$ & 1 & & & 100 \\
\hline & \multicolumn{2}{|c|}{ Daya Total (Watt) } & & & 12280 & $\begin{array}{c}421 \\
0\end{array}$ & 4880 \\
\hline & \multicolumn{2}{|c|}{1 Fasa (Ampere) } & & & 56,957 & $\begin{array}{c}19,5 \\
27\end{array}$ & 22,635 \\
\hline & & (Ampere) & & & & 33,132 & \\
\hline
\end{tabular}

Berdasarkan data tabel 7 ada perbedaan antara beban pengaman yang digunakan pada panel AC lantai 3 , kapasitas pengaman MCB 3 Fasa 50A dengan data analisis beban panel AC lantai 3 kapasitas MCB 3 Fasa 33,132A. Dan data ini sudah terlihat perbedaan penggunaan beban antara fasa $\mathrm{R}, \mathrm{S}, \mathrm{T}$ perbedaan selisi beban fasa $\mathrm{R}$ - $\mathrm{S}$ adalah 8.070 watt, selisi beban fasa $\mathrm{S}-\mathrm{T}$ adalah 670 watt, dan selisi beban fasa $R-T$ adalah 7.400 watt. Ada perbedaan yang terlihat pada fasa $\mathrm{R}$ dengan penggunaan ruang lab. Multi Media untuk beban komputer menggunakan hanya 1 fasa saja. Hal ini tidak sesuai dengan kriteria kehandalan instalasi listrik yang mensyaratkan penggunaan pembatas sesuai dengan pemakaian beban

\section{h. Beban Panel Penerangan Lantai 4}

Tabel 8 Pemakaian Komponen dan Beban Lantai 4 Panel

\begin{tabular}{|c|c|c|c|c|c|c|c|}
\hline \multicolumn{8}{|c|}{ Penerangan } \\
\hline \multirow{2}{*}{ No. } & \multirow{2}{*}{$\begin{array}{c}\text { Ruang } \\
\text { an }\end{array}$} & \multirow{2}{*}{ Item } & \multirow{2}{*}{$\begin{array}{c}\text { Spesifika } \\
\text { si } \\
\end{array}$} & \multirow{2}{*}{$\begin{array}{l}\text { Jum } \\
\text { lah }\end{array}$} & \multicolumn{3}{|c|}{ Daya } \\
\hline & & & & & $\mathrm{R}$ & $\mathrm{S}$ & $\mathrm{T}$ \\
\hline 1 & $\begin{array}{l}\text { Loron } \\
\text { g Lt. } 4\end{array}$ & Lampu TL & $1 \times 36$ watt & 4 & & & 144 \\
\hline \multirow{2}{*}{2} & \multirow{2}{*}{$\begin{array}{l}\text { Ruang } \\
\text { Sidang }\end{array}$} & Lampu Pijar & 18 Watt & 5 & 54 & 36 & \\
\hline & & Stop Kontak & 100 Watt & 2 & 200 & & \\
\hline \multirow{6}{*}{3} & \multirow{6}{*}{$\begin{array}{l}\text { Ruang } \\
\text { Komp } \\
\text { onen } \\
\text { Elektr } \\
\text { onika / } \\
402\end{array}$} & Lampu TL & $1 \times 36$ watt & 2 & 72 & & \\
\hline & & Stop Kontak & 100 Watt & 1 & 100 & & \\
\hline & & Komputer Acer & 450 Watt & 1 & 450 & & \\
\hline & & Televisi Sony & 200 Watt & 1 & 200 & & \\
\hline & & Tipe Recorder & 100 Watt & 1 & 100 & & \\
\hline & & Dispenser & 150 Watt & 1 & 150 & & \\
\hline & & Lampu TL & $1 \times 18$ watt & 2 & 72 & & \\
\hline \multirow{8}{*}{4} & \multirow{8}{*}{$\begin{array}{c}\text { Ruang } \\
\text { Dosen } \\
\text { Lt. } 4\end{array}$} & Stop Kontak & 100 Watt & 2 & 200 & & \\
\hline & & AC Split Dash & $\begin{array}{l}1120 \\
\text { Watt }\end{array}$ & 1 & $\begin{array}{c}112 \\
0\end{array}$ & & \\
\hline & & Komputer Acer & 450 Watt & $\begin{array}{c}2 \\
\text { Set }\end{array}$ & 900 & & \\
\hline & & Televisi Sharp & 200 Watt & 1 & 200 & & \\
\hline & & Printer $\mathrm{Hp}$ & 100 Watt & 1 & 100 & & \\
\hline & & Tipe Recorder & 100 Watt & 1 & 100 & & \\
\hline & & Dispenser & 150 Watt & 1 & 150 & & \\
\hline & & Lampu TL & $3 \times 18$ watt & 6 & 162 & & 162 \\
\hline \multirow{3}{*}{5} & \multirow{2}{*}{$\begin{array}{l}\text { Ruang } \\
407\end{array}$} & Stop Kontak & 100 Watt & 2 & 200 & & \\
\hline & & $\begin{array}{l}\text { Kipas Angin } \\
\text { National }\end{array}$ & 150 Watt & 1 & 150 & & \\
\hline & \multirow{3}{*}{$\begin{array}{c}\text { Ruang } \\
406\end{array}$} & Lampu TL & $2 \times 18$ watt & 4 & & & 144 \\
\hline \multirow{2}{*}{6} & & Printer $\mathrm{Hp}$ & 100 Watt & 1 & & & 100 \\
\hline & & $\begin{array}{l}\text { LCD Proyektor } \\
\text { Benq }\end{array}$ & 150 watt & 1 & & & 150 \\
\hline \multirow{3}{*}{7} & \multirow{4}{*}{$\begin{array}{l}\text { Lab. } \\
\text { Teleko } \\
\text { munik } \\
\text { asi }\end{array}$} & Lampu TL & $2 \times 18$ watt & 6 & & & 216 \\
\hline & & Stop Kontak & 100 Watt & 3 & & 300 & \\
\hline & & Komputer Acer & 450 Watt & $\begin{array}{l}10 \\
\text { Set }\end{array}$ & & $\begin{array}{c}450 \\
0\end{array}$ & \\
\hline \multirow{6}{*}{8} & & Lampu TL & $3 \times 18$ watt & 6 & & 324 & \\
\hline & \multirow{5}{*}{$\begin{array}{c}\text { Ruang } \\
404\end{array}$} & Stop Kontak & 100 Watt & 1 & & 100 & \\
\hline & & $\begin{array}{l}\text { Kipas Angin } \\
\text { National }\end{array}$ & 150 Watt & 1 & & 150 & \\
\hline & & Daya Total (Watt) & & & $\begin{array}{c}468 \\
0\end{array}$ & $\begin{array}{c}541 \\
0\end{array}$ & 916 \\
\hline & & 1 Fasa (Ampere) & & & $\begin{array}{l}21 \\
707\end{array}$ & $\begin{array}{c}25,0 \\
93\end{array}$ & $\begin{array}{c}4,2 \\
49\end{array}$ \\
\hline & & 3 Fasa (Ampere) & & & & 17,064 & \\
\hline
\end{tabular}

Terdapat perbedaan antara beban pengaman yang digunakan pada panel penerangan lantai 4 , kapasitas pengaman MCB 3 Fasa 40A dengan data analisis beban panel Penerangan lantai 4 kapasitas MCB 3 Fasa 17,064A. Dan data ini sudah terlihat perbedaan penggunaan beban antara fasa $R, S, T$ perbedaan selisi beban fasa $R$ - S adalah 730 watt, selisi beban fasa $S-T$ adalah 4.494 watt, dan selisi beban fasa $\mathrm{R}-\mathrm{T}$ adalah 3.764 watt. Ada perbedaan yang terlihat pada fasa $\mathrm{T}$ digunakan beban terlalu sedikit. Hal ini tidak sesuai dengan kriteria kehandalan instalasi listrik yang mensyaratkan penggunaan pembatas sesuai dengan pemakaian beban.

\section{i. Beban Panel AC Lantai 4}

Terdapat perbedaan antara beban pengaman yang digunakan pada panel AC lantai 4, kapasitas pengaman MCB 3 Fasa 50A dengan 
data analisis beban panel AC lantai 4 kapasitas MCB 3 Fasa 25,346A. Dan data ini sudah terlihat perbedaan penggunaan beban antara fasa $R, S, T$ perbedaan selisi beban fasa $\mathrm{R}-\mathrm{S}$ adalah 1.338 watt, selisi beban fasa $\mathrm{S}-\mathrm{T}$ adalah 6.488 watt, dan selisi beban fasa $\mathrm{R}-\mathrm{T}$ adalah 5.150 watt. Ada perbedaan yang terlihat pada fasa $S$ dengan penggunaan ruang 403, ruang dosen D3, dan stop kontak R.407-404 untuk beban praktikum menggunakan hanya 1 fasa saja. Hal ini tidak sesuai dengan kriteria kehandalan instalasi listrik yang mensyaratkan penggunaan pembatas sesuai dengan pemakaian beban.

Tabel 9 Pemakaian Komponen dan Beban Lantai 4 Panel $\mathrm{AC}$

\begin{tabular}{|c|c|c|c|c|c|c|c|}
\hline \multirow{2}{*}{ No. } & \multirow{2}{*}{ Ruangan } & \multirow{2}{*}{ Item } & \multirow{2}{*}{$\begin{array}{c}\text { Spesifika } \\
\text { si }\end{array}$} & \multirow{2}{*}{$\begin{array}{l}\text { Jum } \\
\text { lah }\end{array}$} & \multicolumn{3}{|c|}{ Daya } \\
\hline & & & & & $\mathrm{R}$ & $\mathrm{S}$ & $\mathrm{T}$ \\
\hline 1 & $\begin{array}{l}\text { Ruang } \\
\text { Sidang } \\
\text { Ruang }\end{array}$ & AC Ssplit Dash & $\begin{array}{l}1120 \\
\text { Watt }\end{array}$ & 1 & $\begin{array}{c}112 \\
0\end{array}$ & & \\
\hline \multirow[t]{2}{*}{2} & $\begin{array}{l}\text { Kompon } \\
\text { en } \\
\text { Elektron } \\
\text { ika / } 402\end{array}$ & $\begin{array}{l}\text { Kipas Angin } \\
\text { National }\end{array}$ & 150 Watt & 1 & & 150 & \\
\hline & & AC Split LG & $\begin{array}{l}1120 \\
\text { Watt }\end{array}$ & 3 & & & \\
\hline \multirow[t]{3}{*}{3} & $\begin{array}{c}\text { Ruang } \\
407\end{array}$ & $\begin{array}{l}\text { Stop Kontak } 1 \\
\text { Fasa }\end{array}$ & 100 Watt & 8 & & 800 & \\
\hline & & AC Split Dash & $\begin{array}{l}1120 \\
\text { Watt }\end{array}$ & 1 & & $\begin{array}{c}112 \\
0\end{array}$ & \\
\hline & Ruang & $\begin{array}{c}\text { Stop Kontak } 1 \\
\text { Fasa }\end{array}$ & 100 Watt & 1 & & & 100 \\
\hline \multirow[t]{2}{*}{4} & 406 & $\begin{array}{c}\text { AC Split } \\
\text { Panasonic }\end{array}$ & $\begin{array}{l}1120 \\
\text { Watt }\end{array}$ & 1 & & & 1120 \\
\hline & & $\begin{array}{c}\text { Stopn Kontak } 1 \\
\text { Fasa }\end{array}$ & 100 Watt & 1 & & & 100 \\
\hline \multirow{4}{*}{5} & $\begin{array}{l}\text { Lab. } \\
\text { Telekom }\end{array}$ & $\begin{array}{c}\text { AC Split } \\
\text { Panasonic }\end{array}$ & $\begin{array}{l}1120 \\
\text { Watt }\end{array}$ & 1 & $\begin{array}{c}112 \\
0\end{array}$ & & \\
\hline & unikasi & Televisi & 200 Watt & 1 & & & 100 \\
\hline & & $\begin{array}{l}\text { Kipas angin } \\
\text { National }\end{array}$ & 150 Watt & 1 & & & 150 \\
\hline & Ruang & $\begin{array}{c}\text { AC Split } \\
\text { Panasonic }\end{array}$ & $\begin{array}{l}1120 \\
\text { Watt }\end{array}$ & 2 & $\begin{array}{c}112 \\
0\end{array}$ & $\begin{array}{c}112 \\
0\end{array}$ & \\
\hline \multirow[t]{2}{*}{6} & 404 & $\begin{array}{l}\text { Stop Kontak } 1 \\
\text { Fasa }\end{array}$ & 100 Watt & 8 & & 800 & \\
\hline & & $\begin{array}{c}\text { AC Split } \\
\text { Panasonic }\end{array}$ & $\begin{array}{l}1120 \\
\text { Watt }\end{array}$ & 2 & $\begin{array}{c}112 \\
0\end{array}$ & & \\
\hline & $\begin{array}{l}\text { Ruang } \\
\text { Dosen }\end{array}$ & Lampu TL & $\begin{array}{l}2 \times 36 \\
\text { Watt }\end{array}$ & 2 & & 72 & \\
\hline \multirow{4}{*}{7} & $\begin{array}{l}\text { Dosen } \\
\text { D3 }\end{array}$ & $\begin{array}{l}\text { Stop Kontak } 1 \\
\text { Fasa }\end{array}$ & 100 Watt & 2 & & 200 & \\
\hline & & Komputer Acer & 450 Watt & $\begin{array}{c}2 \\
\text { Set }\end{array}$ & & 900 & \\
\hline & & $\begin{array}{l}\text { Stop Kontak } 1 \\
\text { Fasa }\end{array}$ & 100 Watt & 6 & & 600 & \\
\hline & Ruang & $\begin{array}{c}\text { AC Split } \\
\text { Panasonic }\end{array}$ & $\begin{array}{l}1120 \\
\text { Watt }\end{array}$ & 2 & $\begin{array}{c}112 \\
0\end{array}$ & $\begin{array}{c}120 \\
0\end{array}$ & \\
\hline \multirow{5}{*}{8} & 303 & Lampu TL & & 8 & & 576 & \\
\hline & & $\begin{array}{l}\text { LCD Proyektor } \\
\text { Benq }\end{array}$ & 150 Watt & 1 & & 150 & \\
\hline & & Daya Total (Watt) & & & $\begin{array}{c}672 \\
0\end{array}$ & $\begin{array}{c}805 \\
8\end{array}$ & 15870 \\
\hline & & 1 Fasa (Ampere) & & & $\begin{array}{c}31,1 \\
69\end{array}$ & $\begin{array}{l}37 \\
375\end{array}$ & 7,282 \\
\hline & & 3 Fasa (Ampere) & & & & 25,346 & \\
\hline
\end{tabular}

\section{Hasil Pengukuran PQA}

Tabel 10. Nilai Aktual Frekuensi

\begin{tabular}{cccc}
\hline \multicolumn{3}{c}{ Gedung L UNJ } & \\
\hline Item & $\begin{array}{c}\text { Frekuensi } \\
(\mathrm{Hz})\end{array}$ & $\begin{array}{c}\text { SNI 04- 1922- } \\
\text { 2022 }\end{array}$ & Keterangan \\
\hline Maksimum & 50,25 & & \\
Minimum & 49,78 & $49,5-50,5$ & Sesuai \\
Rata-Rata & 50,00 & & \\
\hline
\end{tabular}

Tabel 11. Nilai Aktual Fluktuasi Tegangan

\begin{tabular}{cccc}
\hline \multicolumn{4}{c}{ Gedung L UNJ } \\
\hline Item & $\begin{array}{c}\text { Tegangan } \\
\text { (Volt) }\end{array}$ & $\begin{array}{c}\text { Permen } \\
\text { ESDM No. 4 } \\
\text { Tahun 2009 }\end{array}$ & Keterangan \\
\hline Maksimum & 240,9 & $-10 \% /+5 \%$ & Sesuai \\
Minimum & 208,6 & (Volt) & \\
Rata-rata & 230,9 & & \\
\hline
\end{tabular}

Tabel 12. Nilai Aktual Nilai Harmonisa

\begin{tabular}{|c|c|c|c|c|c|}
\hline \multicolumn{6}{|c|}{ Gedung L UNJ } \\
\hline \multirow[b]{2}{*}{ Item } & \multicolumn{3}{|c|}{ \% THD Tegangan } & \multirow{2}{*}{$\begin{array}{c}\text { Permen } \\
\text { ESDM } \\
\text { Tahun } \\
2009 \\
\end{array}$} & \multirow[b]{2}{*}{ Keterangan } \\
\hline & $\mathrm{R}$ & S & $\mathrm{T}$ & & \\
\hline Maksimum & 2,2 & 2,4 & 2,2 & \multirow{3}{*}{$\begin{array}{c}\text { Maks. } \\
5 \%\end{array}$} & \multirow{3}{*}{ Sesuai } \\
\hline Minimum & 0,9 & 1,1 & 0,8 & & \\
\hline Rata-rata & 1,5 & 1,5 & 1,2 & & \\
\hline
\end{tabular}

Tabel 13. Nilai Aktual Nilai Harmonisa

\begin{tabular}{cccc}
\hline \multicolumn{3}{c}{ Gedung L UNJ } \\
\hline \multirow{2}{*}{ Item } & $\begin{array}{c}\text { Unb. } \\
\text { Tegangan } \\
(\%)\end{array}$ & $\begin{array}{c}\text { SPLN } \\
\text { D5.004-1 }\end{array}$ & Keterangan \\
\hline Maksimum & 1,3 & 2012 & \\
Minimum & 0,2 & $2 \%$ & Sesuai \\
Rata-rata & 0,5 & & \\
\hline
\end{tabular}

Tabel 14 Nilai Aktual Nilai Faktor Daya

\begin{tabular}{cccc}
\hline \multicolumn{4}{c}{ Gedung L UNJ } \\
\hline Item & $\begin{array}{c}\text { Faktor } \\
\text { Daya (Hz) }\end{array}$ & $\begin{array}{c}\text { Kepres 104 } \\
2003 \text { TDL } \\
2004\end{array}$ & Keterangan \\
\hline Maksimum & 1 & & \\
Minimum & 0.39 & $<0.85$ & Tidak sesuai \\
Rata-rata & 0.78 & & \\
\hline
\end{tabular}

\section{Rekomendasi Peluang Peningkatan Efisiensi Energi}

a. Efisiensi Penerangan

- Menghidupkan lampu sesuai kebutuhan.

- Lakukan perhitungan yang tepat pemasangan armature pada ruangan,sehingga tidak terjadi losses dan overload daya penerangan.

- Mengatur posisi peralatan sehingga tidak mengganggu penerangan.

- Bila memungkinkan, mengganti warna dinding dan langit-langit dengan warna terang sehingga tidak membutuhkan penerangan yang berlebihan.

- Menambah atau mengganti lampu ruangan yang intensitas cahayanya kurang.

\section{b. Efisiensi Kualitas Daya Listrik}

- Memasang filter aktif maupun pasif pada alat elektronik non-liniear untuk menghilangkan distorsi harmonisa pada kelistrikan. 
- Menempelkan stiker atau tempelan himbauan hemat energy pada peralatan listrik yang sering digunakan.

\section{KESIMPULAN DAN SARAN \\ Kesimpulan}

1. Berdasarkan hasil pengukuran menunjukkan bawa frekuensi jaringan listrik yang terpasang di gedung L2 Teknik Elektro masih dalam kategori sesuai antara 49,5-50,5 Hz sesuai dengan standar SNI 04-1922-2002, fluktuasi tegangan jaringan listrik yang terpasang di gedung L2 Teknik Elektro masih dalam kategori sesuaia antara berkisar $-10 \% /+5 \%$ (Volt) sesuai dengan standar Permen ESDM No.4 Tahun 2009, harmonisa tegangan jaringan listrik yang terpasang di gedung L2 Teknik Elektro masih dalam kategori sesuaia masih diangka di bawah 5\% sesuai dengan standar Permen ESDM No.4 Tahun 2009, ketidakseimbangan tegangan jaringan listrik yang terpasang di gedung L2 Teknik Elektro masih dalam kategori sesuaia masih diangka di bawah 2\% sesuai dengan standar SPLN D5.004-1:2012, faktor daya jaringan listrik yang terpasang di gedung L2 Teknik Elektro dalam kategori tidak lebih dari 0,85 sesuai

\section{Saran}

dengan standar Keppres 1042003 TDL 2004

1. Penelitian ini dapat dikembangkan dengan mempertimbangkan kontruksi bangunan dan ventilasi terhadap pemakaian energi listrik.

2. Guna memberikan dampak yang lebih signifikan terhadap penghematan konsumsi energi listrik diperlukan peran serta civitas akademika Teknik Elekro Fakultas Teknik Universitas Negeri Jakarta

\section{DAFTAR PUSTAKA}

Arismunandar, A. dan Kuahara, S. (1973). Teknik Tegangan Tinggi.Jakarta (Jilid III).PT Dainippon Gitakarya Printing.

Azizi, Muhamad Mukhsital. (2015). Analisis Harmonisa Jaringan Listrik (Studi Pada Gedung L Jurusan Teknik Elektro, Fakultas Teknik, Universitas Negeri Jakarta). Skripsi.

Effendi, Abdurachman. (2012). Audit Awal Energi Listrik Pada Gedung Ps Kedokteran Universitas Lampung.Jurnal Ilmiah pada Jurusan Teknik Elektro Fakultas Teknik
Universitas Lampung: Diterbitkan.

Hutagulung, Abdu Rosyiid. (2011) Analisis Kehandalan Instalasi Listrik 3 Fasa Gedung Bertingkat ( Suatu Studi Kasus di Gedung Jurusan Teknik Elektro FT UNJ). Skripsi

Paidjo. dan Haryanto Dedy. et al . (2007). Kuat Penerangan (Iluminasi) Ruang Kendali Utama Untai Uji Termohidrolika PtrknBatan.Jurnal Ilmiah Pusat Teknologi Reaktor dan Keselamatan Nuklir-BATAN: Diterbitkan.

Pasisarha, S Daeng. (2012). Evaluasi IKE Listrik Melalui Audit Awal Energi Listrik di Kampus Polines.Jurnal Ilmiah pada Jurusan Teknik Elektro, Politeknik Negeri Semarang: Diterbitkan.

Pistoniawan, Dani.(2010).Tips Mengetahui Kebutuhan PK AC dan Daya Pendingin (BTU/hr) [Online].

Tersedia:http://www.serviceac.net/pk-acdan-daya-pendingin-btu.php.htm.php[29 September 2012].

Salpanio, Ricky. (2007). Audit Energi Listrik Pada Gedung Kampus Undip Pleburan Semarang.Jurnal Ilmiah pada Jurusan Teknik Elektro Fakultas Teknik Universitas Diponegoro: Diterbitkan.

Sujatmiko, Wahyu. (2008). Penyempurnaan Standar Audit Energi Pada Bangunan Gedung.Jurnal Ilmiah Prosiding PPIS Bandung: Diterbitkan. 